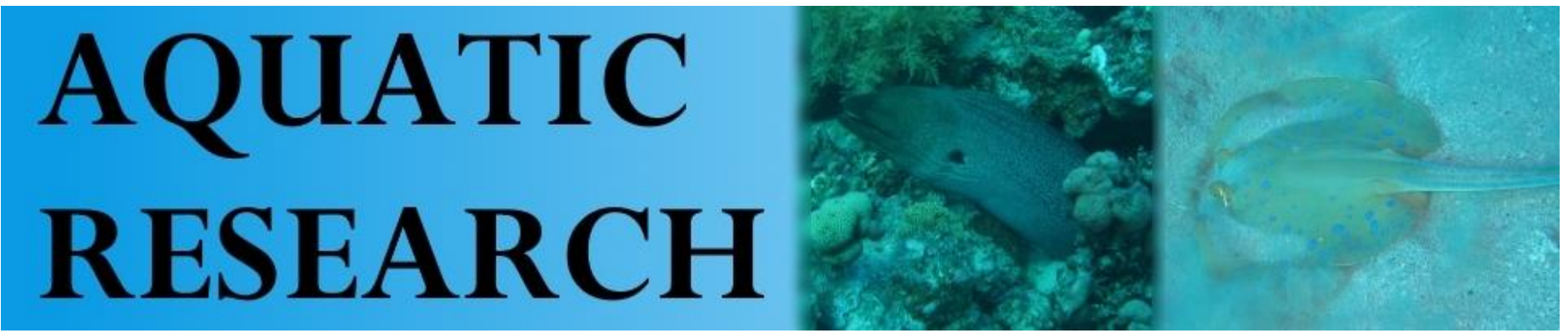

\title{
ACOUSTIC NOISE POLLUTION FROM MARINE INDUSTRIAL ACTIVITIES: EXPOSURE AND IMPACTS
}

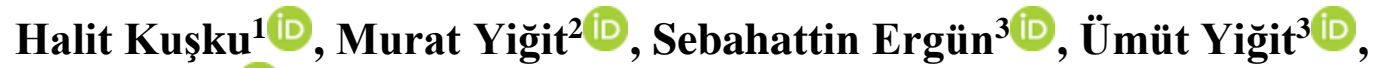 \\ Nic Taylor ${ }^{4}$ iD
}

\section{Cite this article as:}

Kuşku, H., Yiğit, M., Ergün, S., Yiğit, Ü., Taylor, N. (2018). Acoustic Noise Pollution from Marine Industrial Activities: Exposure and Impacts. Aquatic Research, 1(4), 148-161. DOI: 10.3153/AR18017

${ }^{1}$ Canakkale Onsekiz Mart University, School of Applied Sciences at Canakkale, Department of Fisheries, 17100, Canakkale, Turkey

2 Canakkale Onsekiz Mart University, Faculty of Marine Science and Technology, Department of Marine Technology, 17100, Canakkale, Turkey

${ }^{3}$ Canakkale Onsekiz Mart University, Faculty of Marine Science and Technology, Department of Aquaculture, 17100, Canakkale, Turkey

${ }^{4}$ SS Snow-Leopard Research Vessel, Multihull Centre, Foss Quay, Millbrook, Cornwall, PL10 1EN, United Kingdom, UK

Submitted: 02.07.2018

Accepted: 09.08.2018

Published online: 10.08.2018

Correspondence:

Murat YİĞITT

E-mail: muratyigit@ comu.edu.tr

๑Copyright 2018 by ScientificWebJournals

Available online at

http://aquatres.scientificwebiournals.com

\section{ABSTRACT}

The improvements in marine technological developments propagate urbanization in the ocean environment. The construction or operational activities of marine structures such as energy plants, oil platforms, pipe-lines, sea-tunnel passages, or cable-stayed suspension bridges, and vessel traffic are sources of underwater noise pollution. How underwater sounds such as piling, pole drilling, or machinery noises may affect the marine live is mostly ignored in marine construction, and there is lack of information regarding underwater sound effects on marine live in the oceans. Recently, a remarkable interest is developing concerning underwater sound effects, especially in aquaculture facilities, with experimentation of musical stimuli or various noises caused by pumps or filter systems on behavior and stress responses of fish in culture conditions. With the increase of urbanization and progressive development of marine industries, more and more pressure from human-generated (anthropogenic) underwater sound pollution may threaten marine mammals, fish species and invertebrates from underwater noises that in terms might be called as "Underwater Noise Pollution". The future of marine life and that of human being, and the dramatic increase of underwater sound pollution is a new debate that needs to be controlled in a sustainable way with environmentsound approaches. Therefore the potential effects of various sound sources derived from marine industrial activities have been reviewed in this study.

Keywords: Marine industry, Underwater sound, Noise pollution, Anthropogenic noise, Fish behavior 


\section{Introduction}

Acoustic noise pollution generated by marine industrial activities such as the construction of wind energy plants, oil or -gas explorations, cable-stayed suspension bridge, sea-tunnel passage etc. has been increasing in the oceans around the world. The rapid increase of industrialization introduces more and more anthropogenic sounds such as pile driving, pole drilling, dredging, or trenching during the construction works in the marine environment. Not only marine mammals but also a variety of marine living animals is under thread of noise pollution (Popper \& Hawkins 2012). There are several reports on sounds affecting marine mammals (Andrew et al., 2002; Southall et al., 2007), however still many questions remain regarding the hearing capabilities, stress or sound-responses of fish (Kusku et al., 2018) and invertebrates (André et al., 2011), and understanding the potentials of human-made acoustic noise pollution in marine environment. Further, underwater noises from international vessels traffic or coastal fishermen's boats are further sources of acoustic noise to consider. The effects of the shipping industry or recreational boat noises on fish behavior are reported in limited documents related to population assessment or fisheries management, indicating that acoustic noises by ships might influence fish behavior and welfare of fish.

Fish in mass production conditions are often exposed to stress, and is an important criterion for fish welfare, and an important consideration for the assessment of best practice in aquaculture facilities. The most regularly encountered stress conditions such as irregularities in water temperature (Hsieh et al., 2003); fish stocking and hierarchy of dominance (Clement et al., 2005; Gilmour et al., 2005), coloration in culture tanks (Kesbiç et al., 2016), photoperiod regimes (Ergün et al., 2003), or fish transport, handling and husbandry (Kayali et al., 2011), have had limited studies performed to evaluate the effect of such stresses in aquaculture conditions.

Mass production in intensive culture conditions may lead to reduced fish welfare because of a stressful environment that in terms might affect fish health (Hoseinifar et al., 2017; Yousefi et al., 2012). Earlier studies revealed that fish exposed to stressful conditions may alter their physiological conditions such as haematological parameters, which are important criteria for the determination of stress, disease and organ health status in fish (Yilmaz et al., 2013; Yilmaz et al., 2018a,b). Also Barton et al. (1988) reported that blood plasma cortisol and glucose levels are useful indicators for primary or secondary stress conditions in fishes. In goldfish exposed to short-term underwater white noise transmission with a bandwidth ranging from 0.1 to $10 \mathrm{kHz}$ at $160-170 \mathrm{~dB}$ re $1 \mu \mathrm{Pa}$ SPL, plasma cortisol levels were significantly affected by the noise exposure, which was not the case for plasma glucose levels (Smith et al., 2004). The authors found that especially mean cortisol levels tripled over the controls after $10 \mathrm{~min}$ of noise exposure and thereafter declined back to control levels after $60 \mathrm{~min}$ of exposure period. In the long-term noise exposure tests however, the authors underlined that noise exposure did not significantly affect cortisol or glucose concentrations, likely an indication of stress recovery in the long exposure period. Even though, haematological and physiological response parameters could be useful indicators of stress conditions in fish exposed to acoustic noise pollution generated by marine industrial activities. However, there is lack of information regarding haematological and physiological responses in marine animals exposed to stressors of marine industrial noise sources, hence these types of investigations are encouraged in future studies. Furthermore, effects of sounds generated by pumps or filter systems in intensive production such as recirculating aquaculture systems (RAS) are mostly disregarded, and is likely to affect fish welfare and behavior as a response to stressors from noise (Galhardo \& Oliveira, 2009).

Studies on anthropogenic noise effects on marine life are of increasing interest recently (Popper, 2003), and is reported to cause inconsistencies of behavior or habitat selection of marine animals in the natural environment (Popper, 2003; Tolimieri et al., 2002). Further, earlier studies Scholik \& Yan (2001) and Smith et al. (2004) reported that humanmade underwater sound can cause stress and reduce fish welfare (Wysocki et al., 2006). In our recent study (Kusku et al., 2018) we noticed that underwater transmitted sounds such as urban noise may effect fish growth and cause inconsistencies of fish behavior, whereas underwater transmitted musical stimuli was reported to affect fish growth and welfare in a positive manner in common carp (Papoutsoglou et al., 2007; Papoutsoglou et al., 2010), in gilthead sea bream (Papoutsoglou et al., 2008), in turbot (Catli et al., 2015), and in koi fish (Kusku et al., 2018).

There are investigations on-going in the monitoring of the underwater sounds made by marine mammals in the oceans via recording their natural calls with Passive Acoustic Monitoring (PAM) systems, which is also commonly used for the detection of marine mammals (NAI, 2012). The so called PAM system may help to gather information regarding habitat selection or behavior of marine animals in their natural environment. However, in other marine animals such as fish or invertebrates, these systems are not currently in use, since the PAM systems are not capable of identifying 
or detecting the presence of fishes and invertebrates, probably due to the much lower amplitudes of their calls compared to that of marine mammals (NAI, 2012). Considering that radar or sonar systems are capable of detecting a variety of fish species or invertebrates, the use of acoustic monitoring techniques to follow their habitat selection behavior might be feasible without causing any disturbance to their population. The future health of our oceans depends on the rational use and control of human-made effects on the marine environment. Therefore, intensive investigations on the effects of various kinds of industrial sounds such as underwater drilling, piling noises, or dredging on different fish or invertebrate species as well as active acoustic monitoring studies are encouraged for further investigations.

\section{Sources of Underwater Noise Pollution}

Sounds in the marine acoustic environment can be sourced as both natural and human-generated sounds. Human-generated (anthropogenic) sounds other than natural sources can be accepted as the main source of underwater sound pollution. Anthropogenic sounds have a potential threat to marine live and are increasing drastically in recent years (Andrew et al., 2002; Slotte et al., 2004; Tyack, 2008) with the development of marine technologies and growth of maritime industrial activities. Therefore, the level of underwater background noise is becoming a significant problem that threatens the oceans worldwide due to the growing anthropogenic activities in the oceans.

There are several types and sources of underwater noises that might affect marine living organisms in different ways. Pile driving activities are one such source and intensively used in marine constructions and industrial facilities. The effects of pile driving on marine life may vary from size of pile to depth of pile driving. The impacts of industrial noises and underwater sounds on marine organisms can vary based on the metrics for describing the sounds. The type of sound as well as description of sound metrics is necessary to establish information for regulating sound effects on marine life. Further, the size or material used in piling and the bottom substrate might differ in the hydraulic hammer impact necessary for effective piling. Therefore, the methods for measuring sound intensities and impacts of underwater sound generated by pile driving activities are wide areas of study. In the reduction of their environmental impacts, it might be a positive approach to find methods which could minimize the sound level produced during the pile driving work. Since type and size of piles used, as well as the equipment used in piling vary, investigation for measuring sounds the different underwater pile driving approaches might be important for standardization and prediction of their effects on marine life.

Further, pile driving or other sources of underwater noise generated by marine construction industries might cause different levels of noise pollution. Effects of underwater sound generations from construction works such as suspension bridge, ports and piers, including sounds of pile driving, dredging, vibro-densification, or other marine industrial activities such as underwater explosions, can cover an impact area from $100 \mathrm{~m}$ to $1000 \mathrm{~m}$, or even more farther distances from the main sound source (Williams et al., 2014). It is obvious that there is a reduction in sound level with distance (sound transmission loss) as also reported by Bailey et al. (2010). Bailey et al. (2010) investigated underwater sound transmission losses from $0.1 \mathrm{~km}$ (maximum broadband peak of $205 \mathrm{~dB}$ re $1 \mu \mathrm{Pa}$ SPL) to $80 \mathrm{~km}$, and found that these levels of SPL were not any more distinguishable at a distance of $80 \mathrm{~km}$ from the sound source, possible due to a reduction in sound level below the background noise. Additionally, the authors reported that pile driving sound could be detected from a distance of up to $70 \mathrm{~km}$ horizontal range, and their measurements indicated that behavioral disturbance in bottlenose dolphins might have occurred up to a distance of $50 \mathrm{~km}$ from the pile driving sound source. Hence, recorded levels of SPL from underwater field testing and their spectral contents at various distances from the sound source could be evaluated by considering the hearing thresholds of the target marine living organisms in accordance with the ambient noise levels of the specific area. These data together could help to evaluate and predict possible impacts of the sound sources in a horizontal effect-zone.

Marine industrial activities such as pile driving and pole hammer platform at operation for a cable-stayed suspension bridge legs in the Strait of Canakkale are given in Photos 1 and 2. Marine industrial activities such as international shipping lines near cage aquaculture operations and urbanized areas and nearshore ferry lines between two industrial piers are presented in Photos 3 and 4. 


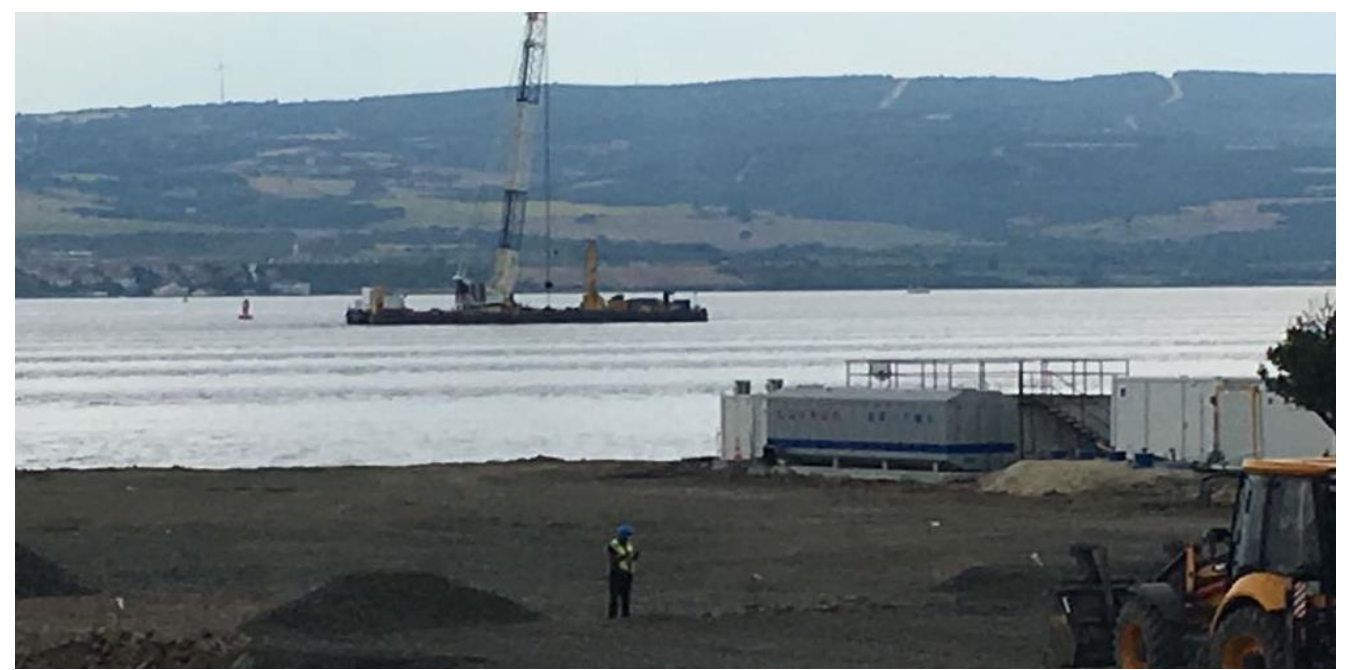

Photo 1. Pile driving platform at operation for suspension bridge construction (original)

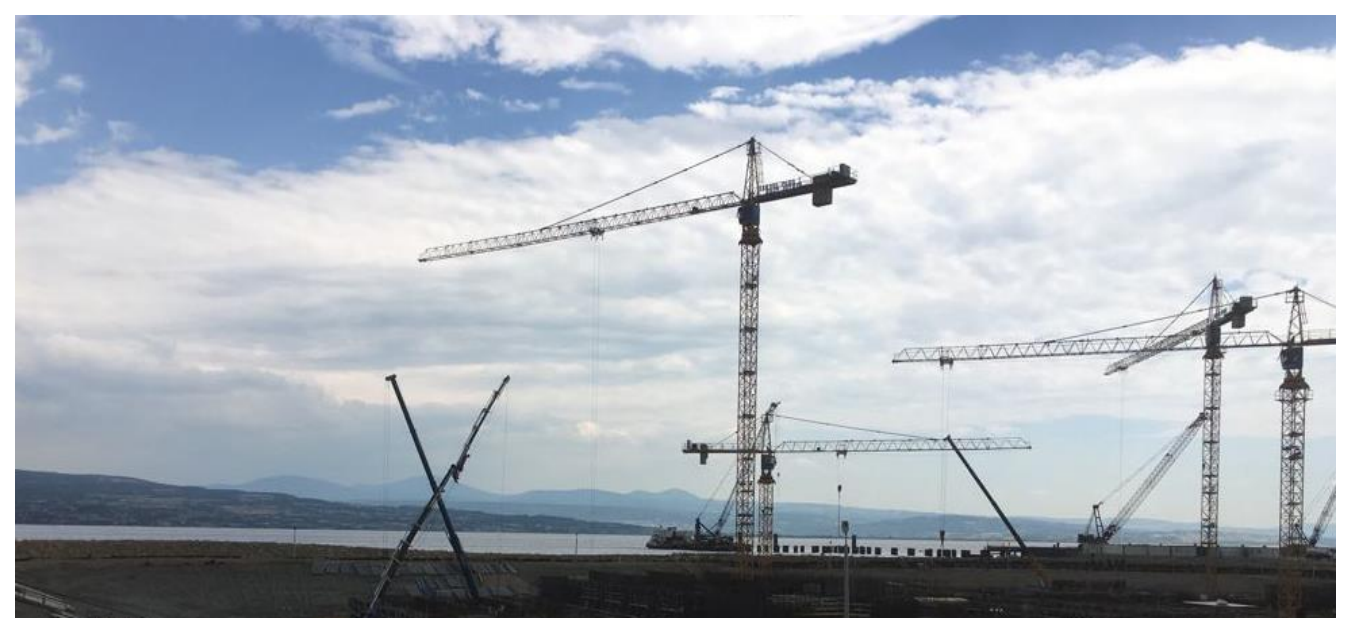

Photo 2. Piling of poles for a suspension bridge legs in the Strait of Canakkale (original)

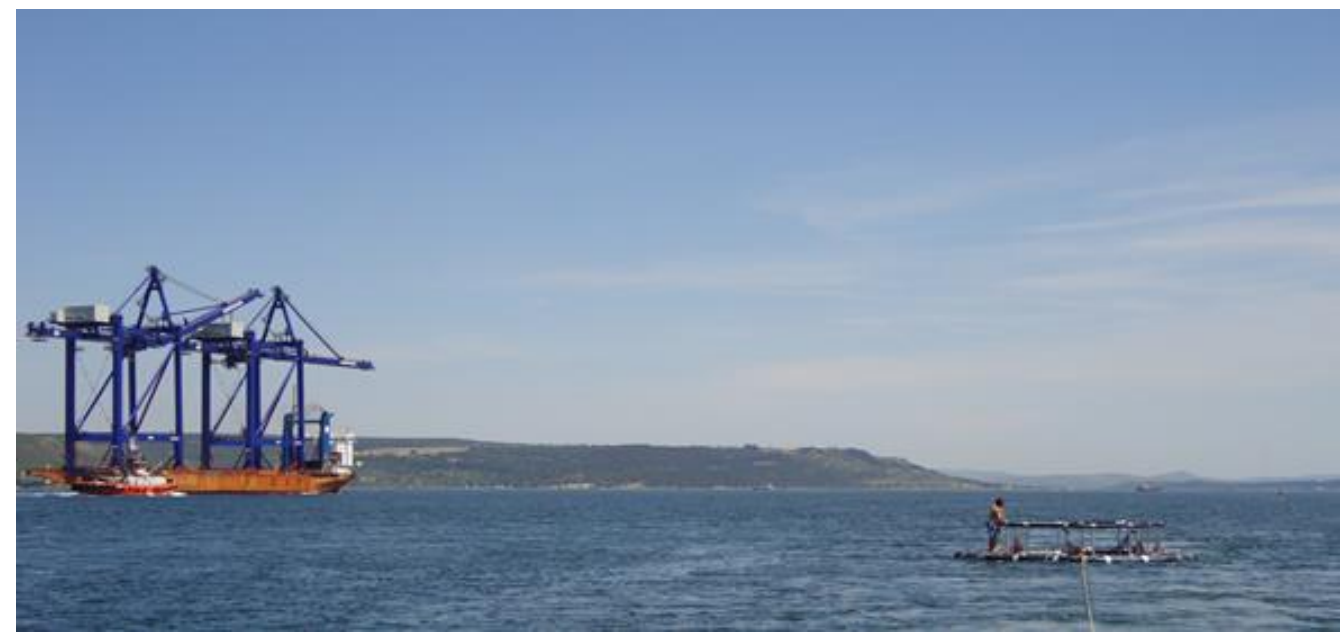

Photo 3. Cage Aquaculture Operations near International Shipping Lines (original) 


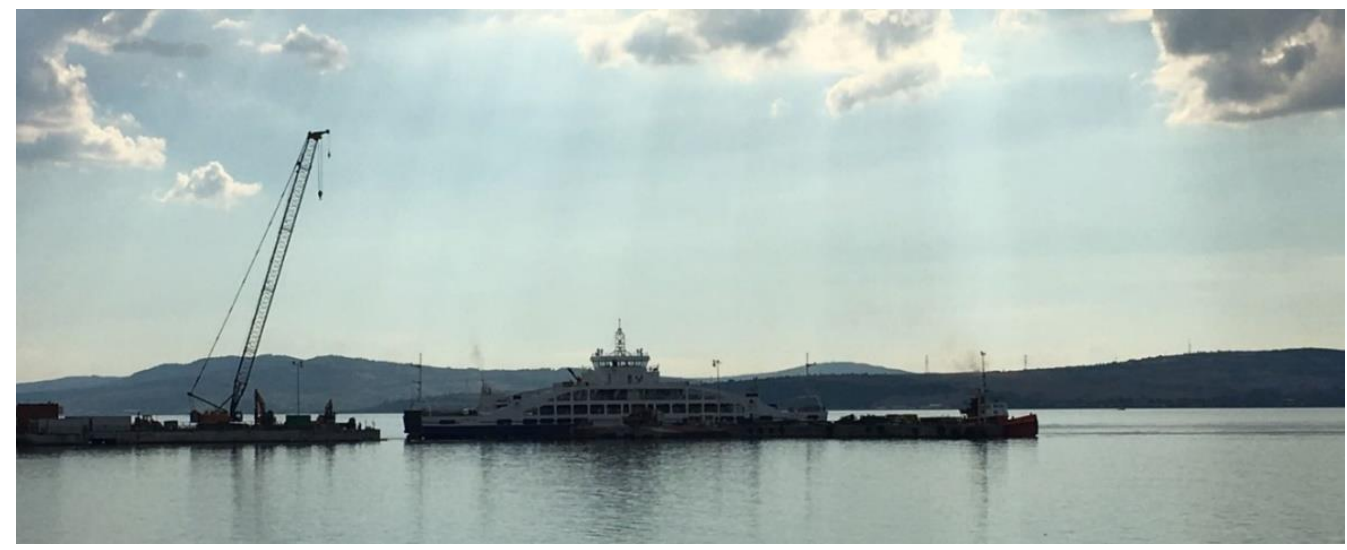

Photo 4. Nearshore Ferry Lines between two industrial piers (original)

Other sources of underwater sound pollution could be attributed to wind energy farms or oil platforms in their construction and operation, these power plants which are deployed on water surface require intensive pile driving during the construction work but also produce a variety of noises during their day to day operation. Commonly they produce different sound pollution spectrums than that produced by drilling for gas explorations of offshore oil or -gas platforms. Wind farms are typically deployed in relative shallow waters, where numerous other sources of underwater sound pollution such as local fishermen boats, coastal ship traffic, touristic activities of motor-boats, surf noises, seismic air-guns used for geophysical studies and sonar systems are available. Among these sources, ships are permanent underwater sound sources which increase the background sound levels.

\section{Sound Pressure Limits, Exposures and Impacts}

The SPL (sound pressure limit) was estimated around 128 $\mathrm{dB}$ (decibel), $1 \mathrm{~m}$ from the sound sources of a wind farm (NAI, 2012). Ambient noise levels in a natural marine environment may differ according to the environmental conditions such as weather state, waves, tidal and anthropogenic impacts of the marine site, as well as depth and bottom conditions. The ambient sound level ranged between 5 and 50 $\mathrm{dB}$ in a natural marine environment (Wenz, 1962). SPLs of 50 to $95 \mathrm{~dB}$ where measured in shallow waters, $1 \mathrm{~m}$ above the sediment (Lagardère, 1982). However, in this discussion, the effect of these noise levels is difficult to determine because of a lack of specific criteria for comparison.
In land-based aquaculture facilities, a significant level of noise are generated due to water pumps, aerators, selection or harvesting machinery, automatic feeding machinery and also various sounds of facility management (Bart et al., 2001). SPLs of $153 \mathrm{~dB}$ re $1 \mu \mathrm{Pa}$ (Bart et al., 2001), and 160 $\mathrm{dB}$ re $1 \mu \mathrm{Pa}$ (Clark et al., 1996) have been reported, which are 100-110 dB higher compared to those in the natural water environment $(5-50 \mathrm{~dB})$. An alarm reflex or involuntary response of fish to un-expected underwater sound might be induced when the average SPL is much higher than the sound level in the background. Neo et al. (2014) reported that an acoustic noise of $165 \mathrm{~dB}$ re $1 \mu \mathrm{Pa}$ SPL could be high enough in level to start the alarm reflex of fish. However, much more information is needed for the evaluation of underwater sound effects on various marine animals with lower or higher SPLs.

Offshore marine fish farms however provide significant benefits due to their location off the coast, reducing visual impacts (Byron \& Costa-Pierce, 2010; Byron et al., 2011), and conflicts with coastal zone users such as tourism (Yigit et al., 2006; Yigit, 2007). Further, improve fish welfare could be expected in cage farms due to better water quality in offshore conditions (Pelegri et al., 2006) with less influence terrestrial effluents and coastal acoustic sounds. Despite the fact that fish in land-based farms are exposed to a wide range of noise, fish in offshore cage systems are subject to sounds caused by machineries used for fish selection, harvesting, or feeding, and the acoustic background noises generated by marine shipping lines and boats. 
It is likely that un-expected acoustic noise might induce a reaction in the Mauthner cells, which are responsible of initiating alarm reflex in fish, this was reported earlier in seabass (Dicentrarchus labrax) juveniles (Spiga et al., 2017) or koi fish (Cyprinus carpio) (Kusku et al., 2018). An involuntary alarm reflex is mediated by a pair of hindbrain Mauthner neurons (Szabo et al., 2006). Physiological stress responses in marine animals to unusual surrounding noises generally appear as stimulation of nervous activity, increase in metabolism, and decreased immune system. When sound pressure levels similar or less than the background acoustic conditions are provided by human activities, it is likely that marine animals may not be disturbed, possible due to the less and insufficient level of sound to trigger alarm reflex (Spiga et al., 2017; Kusku et al., 2018).

Diminishing effects on foraging behavior in marine animals have been recorded as a fear-response when exposed to underwater noise, unusual to their natural ambient. This lowered feeding and increased metabolic rate lead to a reduction in growth performance (Kusku et al., 2018). The disturbance of voluntary feeding caused by anxiety or predator reflex of juvenile Atlantic salmon has also been reported by Metcalfe et al. (1987). The loss of appetite is an expected response of physiological stress (Wendelaar Bonga, 1997), possibly caused by the induced alarm reflex of fish exposed to underwater noise (Kusku et al., 2018). Fish growth, feeding efficiency and behavior in fish were negatively affected by underwater transmission of urban noise playback at $67 \mathrm{~dB}$ re 1 $\mu \mathrm{Pa}$ SPL compared to those held under ambient-noise playback of $57 \mathrm{~dB}$ re $1 \mu \mathrm{Pa}$ SPL (Kusku et al., 2018), also an indication of incline in metabolic rate.

More information on behavioral responses of various marine organisms to anthropogenic underwater noise exposures are presented in Table 1.

White whales (Delphinapterus leucas) are reported to present significant increase of norepinephrine, epinephrine and dopamine levels when exposed to high level (>100 kPa) of sound exposure near a seismic water gun. In this study, Romano et al. (2004) recorded peak pressure levels of impulse between 198 and $226 \mathrm{~dB}$ re $1 \mu \mathrm{Pa}$ peak pressure (8-200 $\mathrm{kPa})$ than those in a non-noise polluted area without sound exposure or exposures of lower than $100 \mathrm{kPa}$, which could be attributed to a possible reflection of nervous activation effect of noise exposure. The authors (Romano et al., 2004) also reported an important increase in aldosterone and significant decline in monocytes in bottlenose dolphins (Turiops truncates), after exposure to seismic air-gun noise at $213-226 \mathrm{~dB}$ re $1 \mu \mathrm{Pa}$ peak pressure $(44-207 \mathrm{kPa})$. A shore crab (Carcinus maenas) was reported to require higher levels of dissolved oxygen when exposed to ship-noise playback in a controlled environment compared to those held under ambient-noise, showing a sign of increased metabolic rate (Wale et al., 2013). Increased physiological activity was also reported in white whales (D. leucas) after exposure of underwater noise from shipping industry (Lyamin et al., 2011).

Richardson et al. (1995) reported different typologies of acoustic noises generated by the marine industry. An oil-gas exploration activity might generate SPLs between 119-127 $\mathrm{dB}$ re $1 \mu \mathrm{Pa}$ from oil drilling, and $131-135 \mathrm{~dB}$ re $1 \mu \mathrm{Pa}$ from pile driving activities. A drill vessel could generate an acoustic noise of 174-185 dB re $1 \mu \mathrm{Pa}$ SPL, whereas seismic air-guns could even cause higher levels of SPLs over 240 $\mathrm{dB}$ re $1 \mu \mathrm{Pa}$ (Richardson et al., 1995). A gross tonnage tanker or container vessel could generate an acoustic noise of 130-205 dB re $1 \mu \mathrm{Pa}$ SPL (Gisiner et al., 1998; Williams et al., 2014), while less SPLs of $150-175 \mathrm{~dB}$ re $1 \mu \mathrm{Pa}$ are recorded for small or medium size ships (ferry) or motor boats in the near shore area (Richardson et al., 1995).

Anthropogenic underwater noises show differences in terms of frequency, sound pressure level (SPL) and duration of exposure. Some of the acoustic sounds generated by several marine industrial activities have been given in Table 2 .

There are evidence that hearing capabilities differ among marine species and the influence of human-made acoustic noises on behavior or welfare of marine animals are species specific (Smith et al., 2004; Davidson et al., 2009; Voellmy et al., 2014). Hence, this needs to be considered in the investigations on natural marine life as well, with the consistent monitoring of sound effects on behavior and distribution of the populations for a comprehensive understanding of acoustic ecology and assessing potential noise impacts on marine animals.

Some earlier studies have underlined that fish may attune to environmental conditions of long-term exposures to high levels of underwater sound pressure limits $(149 \mathrm{~dB}$ re $1 \mu \mathrm{Pa}$ - $160 \mathrm{~dB}$ re $1 \mu \mathrm{Pa}$ SPL) in aquaculture facilities (Wysocki et al., 2007; Davidson et al., 2009). Fish could even develop tolerance to repeated exposure to underwater sounds such as motorboat-noise, and behavioral and physiological responses of fish decreased after a certain time, even a week after sound exposure (Nedelec et al., 2016). Since it is almost impossible to discourage human beings from urbanization or industrialization, it seems to be important to figure out the "threshold limit" of sound that is acceptable by -or less harmful to -marine living organisms. 
Table 1. Behavioral effects of human-generated acoustic noise exposures on marine animals

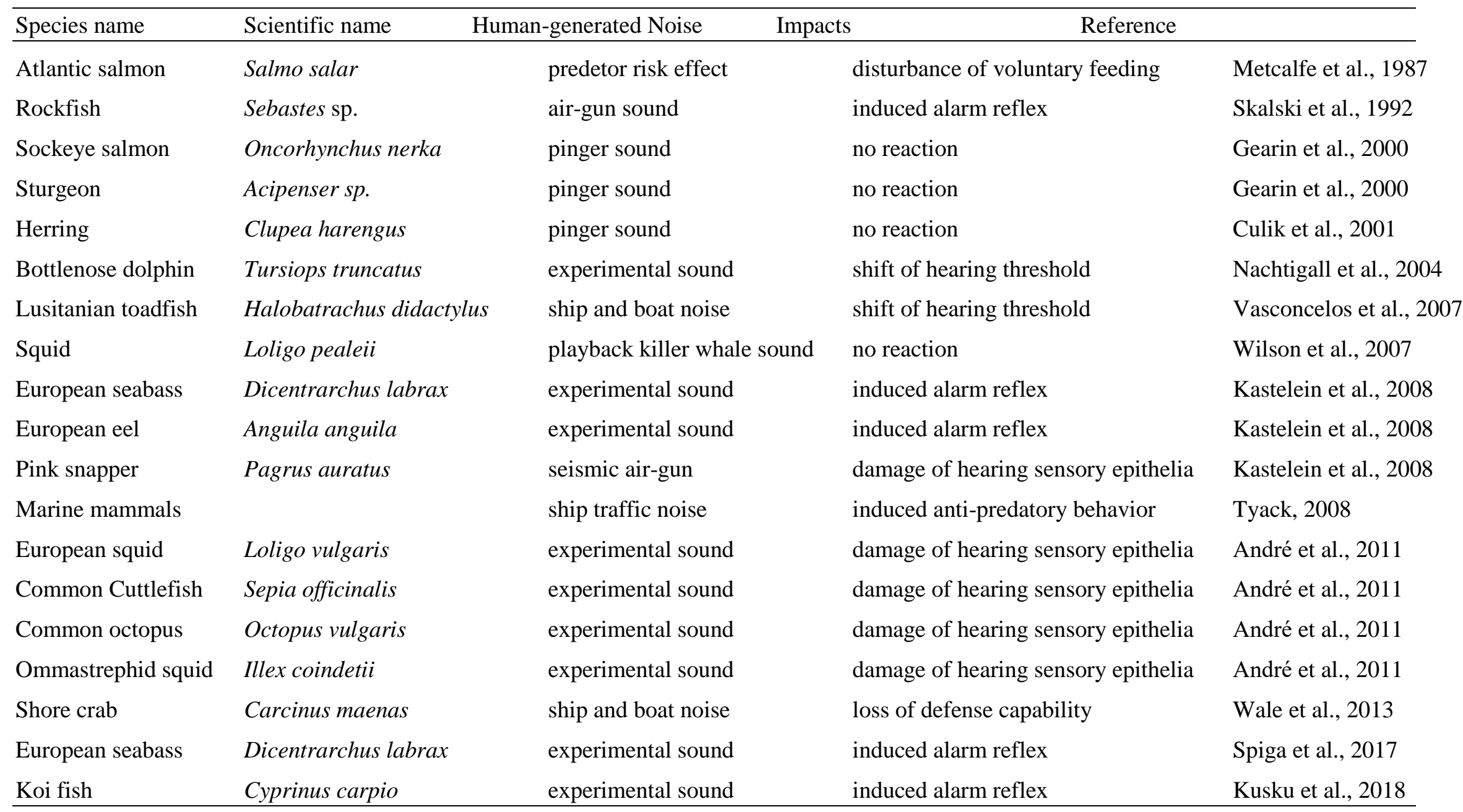


Table 2. Sound pressure levels (SPL) of human-generated acoustic noise exposures in marine environment

\begin{tabular}{lll}
\hline Human-generated Acoustic Noise & $\begin{array}{l}\text { Sound Pressure Limit (SPL) } \\
(\text { from highest to lowest range })\end{array}$ & Reference \\
\hline Seismic air-guns & $240-250 \mathrm{~dB}$ re $1 \mu \mathrm{Pa}$ & Richardson et al., 1995 \\
Seismic air-guns & $195-210 \mathrm{~dB}$ re $1 \mu \mathrm{Pa}$ & Wardle et al., 2001 \\
Seismic air-guns & $186-191 \mathrm{~dB}$ re $1 \mu \mathrm{Pa}$ & Skalsky et al., 1992 \\
Drill vessel & $174-185 \mathrm{~dB}$ re $1 \mu \mathrm{Pa}$ & Richardson et al., 1995 \\
Ship noise (dynamic sea conditions) & $173-185 \mathrm{~dB}$ re $1 \mu \mathrm{Pa}$ & Chen et al., 2017 \\
Piling noise & $164 \mathrm{~dB}$ re $1 \mu \mathrm{Pa}$ & Spiga et al., 2017 \\
Small or medium size vessels (ferry \& motorboat) & $150-180 \mathrm{~dB}$ re $1 \mu \mathrm{Pa}$ & Richardson et al., 1995 \\
Ship noise (engine exhausts, in port) & $135-142 \mathrm{~dB}$ re $1 \mu \mathrm{Pa}$ & EPA, 2010 \\
Pile driving, pole hammer & $131-135 \mathrm{~dB}$ re $1 \mu \mathrm{Pa}$ & Richardson et al., 1995 \\
Ship noise (Marine tanker or container vessel) & $130-205 \mathrm{~dB}$ re $1 \mu \mathrm{Pa}$ & Gisiner et al., 1998; Williams et al., 2014 \\
Ship noise (cruise line) & $130 \mathrm{~dB} \mathrm{re} 1 \mu \mathrm{Pa}$ & Williams et al., 2014 \\
Oil-gas drilling exploration & $119-127 \mathrm{~dB}$ re $1 \mu \mathrm{Pa}$ & Richardson et al., 1995 \\
Research boat (whale-watching) & $108-116 \mathrm{~dB}$ re $1 \mu \mathrm{Pa}$ & Williams et al., 2002a,b \\
Ship noise (ventilation fans, in port) & $81-110 \mathrm{~dB}$ re $1 \mu \mathrm{Pa}$ & EPA, 2010 \\
Ship noise (mean annual basis) & $80-135 \mathrm{~dB}$ re $1 \mu \mathrm{Pa}$ & Merchant et al., 2014
\end{tabular}


Among various kinds of sound sources as of acoustic noise, ships are permanent underwater sound sources which increase the background sound level. Considering that fish can develop tolerance to repeated exposure to underwater motorboat-sounds after a certain time of sound exposure (Nedelec et al., 2016), or even might acclimatize to environmental conditions in long-term when exposed to high levels of SPLs (149 dB re $1 \mu \mathrm{Pa}-160 \mathrm{~dB}$ re $1 \mu \mathrm{Pa})$ (Clark et al., 1996; Wysocki et al., 2007; Davidson et al., 2009), the longterm effect from the shipping industry is likely to be acceptable by marine animals. However further research is necessary to collect more precise information. Moreover, all the underwater noises from different industrial sources in coastal marine environment over a long-time might produce a cumulative effect that needs to be considered in general.

It is likely that short term marine operations such as construction works of piers, cable-stayed suspension bridge or sea-tunnel passage are of significant concern with acoustic sound pollution through pile driving, pole drilling, dredging, or trenching during the construction works trigger considerable biological impacts on marine life such as exclusion or loss of habitat, incoherencies of behavior of marine animals. The noise pollution generated during the operational phase of wind farms is probably not a significant problem for marine life since fish might adapt to environmental noises in a long-term (Wysocki et al., 2007; Davidson et al., 2009; Nedelec et al., 2016). However, the sounds generated during the construction phase of the industrial plants are already serious problems to be considered.

Some earlier studies reported underwater noise from pile driving in marine constructions (Nedwell et al. 2003, Blackwell et al. 2004, Rodkin \& Reyff, 2004). During construction, not only the size of the pile or hammer, but also the characteristics of the sea bottom are important that influence the noise level and the strength of the frequency of the sounds generated (Rodkin \& Reyff, 2004). In wind farm constructions, large pile driving units are used because of the large foundations size. The frequency can be around 500 $\mathrm{Hz}$, and the SPL can reach more than $200 \mathrm{~dB}$ re $1 \mu \mathrm{Pa}$ at a distance of $100 \mathrm{~m}$ (PIDP, 2001; Madsen et al., 2006), which seems to be much higher than the acoustic noise of $165 \mathrm{~dB}$ re $1 \mu \mathrm{Pa}$ SPL, a level that is high enough to start an alarm reflex of fish (Neo et al., 2014). Due, it is a clear evidence that more research is necessary in order to assess and evaluation underwater noise effects in marine living organisms exposed to different SPLs at changing frequencies.

Once the wind turbines are deployed in a wind energy farm, the noise from a wind turbine during operation is generated through vibrations which are transferred in to the water ambience and the sea bottom via the turbine foundations. The sound intensity may differ according to size of the wind turbine and the foundation, as well as function of direction from the wind turbine, but it was reported that the directionality has not been assessed or taken into account so far in earlier studies conducted on wind turbine noise influences (Madsen et al., 2006). Therefore, it is important to perform experimentations on underwater noises and biological responses of fish and invertebrates, to be able to focus on possible path to minimize the influences of underwater sounds produced during the construction works of marine structures.

Regarding the use of acoustic monitoring and electronic devices for the detection of the presence of fish and invertebrates, such as sonar or radar systems it is probably feasible to develop equipment that produces a reasonable SPL lower than the thresholds without disturbing marine live. Therefore, the application of active acoustic monitoring is an issue for further exploration.

Even if some kinds of acoustic noises can be tolerated by marine animals as far as they do not exceed the hearing thresholds of the animals, as noted also by Neo et al. (2014) who reported an acoustic noise level of $165 \mathrm{~dB}$ re $1 \mu \mathrm{Pa}$ as a SPL high enough to trigger the alarm-reflex of fish as a fear response to predator attack. For highly sensitive species such as Lusitanian toadfish (Halobatrachus didactylus) and goldfsh (Cyprinus carpio), relatively lower hearing thresholds of SPL below $100 \mathrm{~dB}$ re $1 \mu \mathrm{Pa}$ and less than $75 \mathrm{~dB}$ re 1 $\mu \mathrm{Pa}$ were reported by Vasconcelos et al. (2007) and Gutscher et al. (2011), respectively. Iversen (1967) reported that yellowfin tuna (Thunnus albacares), another soundsensitive species is capable to detect sounds of $89 \mathrm{~dB}$ re 1 $\mu \mathrm{Pa}$.

Since it is almost impossible to discourage human beings from urban life or industrialization, it seems to be important to calculate the "threshold limits" of sounds that are acceptable by -or less harmful to -marine living organisms.

Earlier studies, described above, present findings of effects from stressors, however, "what are the environmental impacts of these stressors?" This is the main question to be considered as a whole, since the impacts can emerge either within a population or a community of a species, in terms of migration, habitat change or even loss of the population due to diminishing effects on foraging behavior of the species, as also reported as a fear-response in earlier studies (Metcalfe et al., 1987; Wendelaar Bonga, 1997; Kusku et al., 2018). This type of impacts on marine living organisms 
can occur either through direct or indirect differentiation of biotic or physical conditions. Even if there are no significant evidences on population changes in the environment, any other likely alterations in the ecological processes, such as altered primary production, or increased nutrients in a trophic chain. Even though these kinds of secondary effects might be difficult to conceive in a total ecosystem, they are important to consider when assessing environmental impacts in long-term especially when cumulative effects are the interest of research.

\section{Conclusions}

As a conclusion, in order to research any potential landmarks for novel procedures to attenuate marine noise pollution, reliable information on acoustic noises needs collected from ongoing marine industry activities. An important question remains as to "how much is the noise impact of the industrial activity" and "what is the additional sound pressure level generated by the industry?" In order to understand the environmental effects of these kinds of marine industrial construction works, information on the natural back-ground noise is necessary prior to establishment of the power plants. Therefore, researchers are encouraged to work directly with the counterparts from the marine industries such as bridge construction, wind energy farms, oil or -gas exploration, which are responsible for generating a significant level of acoustic noises. This might be a successful start for the criteria to be considered in future decision-making path.

\section{References}

André, M., Solé, M., Lenoir, M., Durfort, M., Quero, C., Mas, A., Lombarte, A., van der Shaar, M., LópezBejar, M., Morell M., Zaugg S., Houégnian, L. (2011). Low-frequency sounds induce acoustic trauma in cephalopods. Frontiers in Ecology and the Environment, 10, $18-28$.

Andrew, R.K., Howe, B.M., Mercer, J.A. (2002). Ocean ambient sound: Comparing the 1960s with the 1990s for a receiver off the California coast. Acoustics Research Letters Online, 3, 65-70.

Bart, A., Clark, J., Young, J., Zohar, Y. (2001). Underwater ambient noise measurements in aquaculture systems: a survey. Aquacultural Engineering, 25(2), 99-110.

Barton, B.A., Schreck, C.B., Fowler, L.G. (1988). Fasting and diet content affect stress-induced changes in plasma glucose and cortisol in juvenile Chinook salmon. Progressive Fish-Culturist, 50, 16-22.
Bailey, H., Senior, B., Simmons, D., Rusin, J., Picken, G., Thompson, P.M. (2010). Assessing underwater noise levels during pile-driving at an offshore windfarm and its potential effects on marine mammals. Marine Pollution Bulletin, 60, 888-897.

Blackwell, S.B., Lawson, J.W., Williams, J.T. (2004). Tolerance by ringed seals (Phoca hispida) to impact pipedriving and construction sounds at an oil production island. Journal of the Acoustical Society of America, 115, 2346-2357.

Byron, C., Costa-Pierce, B.A. (2010). Carrying capacity tools for use in the implementation of an ecosystems approach to aquaculture. Site selection and carrying capacity for inland and coastal aquaculture, 87-101.

Byron, C., Bengtson, D., Costa-Pierce, B., Calanni, J. (2011). Integrating science into management: ecological carrying capacity of bivalve shellfish aquaculture. Marine Policy 35, 363-370.

Catli, T., Yildirim, O., Turker, A. (2015). The Effect of Different Tempos of Music During Feeding, on Growth Performance, Chemical Body Composition, and Feed Utilization of Turbot (Psetta maeotica, Pallas 1814). The Israeli Journal of Aquaculture - Bamidgeh, IJA_67.2015.1221.

Chen, F., Shapiro, G.I., Bennett, K.A., Ingram, S.N., Thompson, D., Vincent, C., Russell, D.J.F., Embling, C.B. (2017). Shipping noise in a dynamic sea: a case study of grey seals in the Celtic Sea. Marine Pollution Bulletin, 114, 372-383.

Clark, J., Young, J., Bart, A., Zohar, Y. (1996). Underwater ambient noise measurements. 30th Proceedings of the Acoustical Society of America. St. Louis, MO, November, 27, 13.

Clement, T.S., Parikh, V., Schrumpf, M., Fernald, R.D. (2005). Behavioral coping strategies in a cichlid fish: the role of social status and acute stress response in direct and displaced aggression. Hormones and behavior, 47(3), 336-342.

Culik, B.M., Koschinski, S., Tregenza, N., Ellis, G.M. (2001). Reactions of harbor porpoises Phocoena phocoena and herring Clupea harengus to acoustic alarms. Marine Ecology Progress Series, 211, 255-260. 
Davidson, J., Bebak, J., Mazik, P. (2009). The effects of aquaculture production noise on the growth, condition factor, feed conversion, and survival of rainbow trout, Oncorhynchus mykiss. Aquaculture, 288(3-4), 337343.

EPA, (2010). Environmental Protection Agency Report. Noise from ships in ports Possibilities for noise reduction. Environmental Project No. 1330 2010, Miljøprojekt, Lloyd's Register ODS, Danish Ministry of Environment.

Ergün, S., Yigit, M., Türker, A. (2003). Growth and feed consumption of young rainbow trout (Oncorhynchus mykiss) exposed to different photoperiods. Israeli Journal of Aquaculture - Bamidgeh, 55(2), 132-138.

Galhardo, L., Oliveira, R.F. (2009). Psychological stress and welfare in fish. Annual Review of Biomedical Sciences, $11,1-20$.

Gearin, P.J., Gosho, M.E., Lakke, J.L., Cooke, L., Delong, R.L., Hughes, K.M. (2000). Experimental testing of acoustic alarms (pingers) to reduce bycatch of harbor porpoise, Phoceoena phocoena, in the state of Washington. Journal of Cetacean Research and Management, 2(1), 1-9.

Gilmour, K.M., DiBattista, J.D., Thomas, J.B. (2005). Physiological causes and consequences of social status in salmonid fish. Integrative and comparative biology, 45(2), 263-273.

Gisiner, R., Cudahy, E., Frisk, G., Gentry, R., Hofman, R., Popper, A., Richardson, W.J. (1998). Proceedings of the Workshop on the Effects of Anthropogenic Noise in the Marine Environment, Office of Naval Research: Arlington, VA, USA.

Gutscher, M., Wysocki, L.E., Ladich, F. (2011). Effects of aquarium and pond noise on hearing sensitivity in an otophysine fish. The International Journal of Animal Sound and its Recording, 20, 117-136.

Hoseinifar, S.H., Dadar, M., Ringø, E. (2017). Modulation of nutrient digestibility and digestive enzyme activities in aquatic animals: The functional feed additives scenario. Aquaculture Research, 48, 3987-4000.
Hsieh, S., Chen, Y., Kuo, C. (2003). Physiological responses, desaturase activity, and fatty acid composition in milkfish (Chanos chanos) under cold acclimation. Aquaculture, 220(1-4), 903-918.

Iversen, R.T.B. (1967). Response of the yellowfin tuna (Thunnus albacares) to underwater sound. In: Marine Bio-Acoustics II, ed. W.N. Tavolga, 105-121. New York: Pergamon Press.

Kastelein, R.A., van der Heul, S., Verboom, W.C., Jennings, N., van der Veen, J., de Haan, D. (2008). Startle response of captive North Sea fish species to underwater tones between 0.1 and $64 \mathrm{kHz}$. Marine Environmental Research, 65, 369-377.

Kayali, B., Yigit, M., Bulut, M. (2011). Evaluation of the recovery time of sea bass (Dicentrarchus labrax Linnaeus, 1758) juveniles from transport and handling stress: using ammonia nitrogen excretion rates as a stress indicator. Journal of Marine Science and Technology, 19(6), 681-685.

Kesbiç, O. S., Yiğit, M., Acar, Ü. (2016). Effects of tank color on growth performance and nitrogen excretion of european seabass (Dicentrarchus labrax) juveniles. Proceedings of the National Academy of Sciences, India Section B: Biological Sciences, 86(1), 205-210.

Kusku, H., Ergün, S., Yilmaz, S., Güroy, B., Yigit, M. (2018). Impacts of Urban Noise and Musical Stimuli on Growth Performance and Feed Utilization of Koi fish (Cyprinus carpio) in Recirculating Water Conditions. Turkish Journal of Fisheries and Aquatic Sciences, 19(6), http://doi.org/10.4194/1303-2712v19_6_07.

Lagardère, J. (1982). Effects of noise on growth and reproduction of Crangon crangon in rearing tanks. Marine Biology, 71(2), 177-185.

Lyamin, O.I., Korneva, S.M., Rozhnov, V.V., Mukhametov, L.M. (2011). Cardiorespiratory changes in beluga in response to acoustic noise. Doklady Biological Science. $440,257-258$.

Madsen, P.T., Wahlberg, M., Tougaard, J., Lucke, K., Tyack, P. (2006). Wind turbine underwater noise and marine mammals: implications of current knowledge and data needs. Marine Ecology Progress Series, 309, 279-295. 
Merchant, N.D., Pirotta, E., Barton, T.R., Thompson P.M. (2014). Monitoring ship noise to assess the impact of coastal developments on marine mammals. Marine Pollution Bulletin, 78, 85-95.

Metcalfe, N.B., Huntingford, F.A., Thorpe, J. E. (1987). The influence of predation risk on the feeding motivation and foraging strategy of juvenile Atlantic salmon. Animal Behaviour, 35(3), 901-911.

Nachtigall, P.E., Supin, A.Y., Pawloski, J., Au, W.W. (2004). Temporary threshold shifts after noise exposure in the bottlenose dolphin (Tursiops truncatus) measured using evoked auditory potentials. Marine Mammal Science, 20, 673-687.

NAI, (2012). Normandeau Associates, Inc. 2012. Effects of Noise on Fish, Fisheries, and Invertebrates in the U.S. Atlantic and Arctic from Energy Industry Sound-Generating Activities. A Workshop Report for the U.S. Dept. of the Interior, Bureau of Ocean Energy Management. Contract \#M11PC00031. 72 pp. plus Appendices.

Nedelec, S.L., Mills, S.C., Lecchini, D., Nedelec, B., Simpson, S. D., Radford, A.N. (2016). Repeated exposure to noise increases tolerance in a coral reef fish. Environmental pollution, 216, 428-436.

Nedwell, J.D., Langworthy, J., Howell, D. (2003). Assessment of subsea acoustic noise and vibration from offshore wind turbines and its impact on marine life. Cowrie Report, 544 R-0424, 1-68.

Neo, Y., Seitz, J., Kastelein, R., Winter, H., Ten Cate, C., Slabbekoorn, H. (2014). Temporal structure of sound affects behavioural recovery from noise impact in European seabass. Biological Conservation, 178, 65-73.

Papoutsoglou, S., Karakatsouli, N., Batzina, A., Papoutsoglou, E., Tsopelakos, A. (2008). Effect of music stimulus on gilthead seabream Sparus aurata physiology under different light intensity in a re-circulating water system. Journal of Fish Biology, 73(4), 980-1004

Papoutsoglou, S., Karakatsouli, N., Louizos, E., Chadio, S., Kalogiannis, D., Dalla, C., Polissidis, A., Papadopoulou-Daifoti, Z. (2007). Effect of Mozart's music (Romanze-Andante of "Eine Kleine Nacht Musik", sol major, K525) stimulus on common carp (Cyprinus carpio
L.) physiology under different light conditions. Aquacultural engineering, 36(1), 61-72.

Papoutsoglou, S.E., Karakatsouli, N., Papoutsoglou, E.S., Vasilikos, G. (2010). Common carp (Cyprinus carpio) response to two pieces of music ("Eine Kleine Nachtmusik" and "Romanza") combined with light intensity, using recirculating water system. Fish Physiology and Biochemistry, 36(3), 539-554.

Pelegri, J.L., Marrero-Diaz, A., Ratsimandresy, A.W. (2006). Nutrient irrigation of the North Atlantic. Progress in Oceanography, 70, 366-406.

PIDP, 2001. Pile Installation Demonstration Project, San Francisco-Oakland Bay Bridge, East Span Seismic Safety Project, Fisheries Impact Assessment. PIDP EA 012081, Caltrans contract 04A0148, Task Order 205.10.90, PIDP 04-ALA-80-0.0/0.5, p 1-68.

Popper, A.N. (2003). Effects of anthropogenic sounds on fishes. Fisheries, 28(10), 24-31.

Popper, A.N., Hawkins, A.D. (2012). The effects of noise on aquatic life. New York: Springer Science + Business Media, LLC.

Richardson, W.J., Finley, K.J., Miller, G.W., Davis, R.A., Koski, W.R. (1995). Feeding, social and migration behavior of bowhead whales, Balaena mysticetus, in Baffin Bay vs. the Beaufort Sea-Regions with different amount of human activity. Marine Mammal Science, $11,1-45$.

Rodkin, R.B., Reyff, J.A. (2004). Underwater sound pressures from marine pile-driving. Journal of the Acoustical Society of America, 116, 2648.

Romano, T.A., Keogh, M.J., Kelly, C., Feng, P., Berk, L., Schlundt, C.E., Carder, D.A., Finneran, J.J. (2004). Anthropogenic sound and marine mammal health: Measures of the nervous and immune systems before and after intense sound exposure. Canadian Journal of Fisheries and Aquatic Sciences, 61: 1124-1134.

Scholik, A.R., Yan, H.Y. (2001). Effects of underwater noise on auditory sensitivity of a cyprinid fish. Hearing research, 152(1-2), 17-24. 
Skalski, J.R., W.H. Pearson, Malme, C.I. (1992). Effects of sound from a geophysical survey device on catch-per unit in a hook-and-line fishery for rockfish (Sebastes spp.). Canadian Journal of Fisheries and Aquatic Sciences, 49, 1357-1365.

Slotte, A., Hansen, K., Dalen, J., Ona, E. (2004). Acoustic mapping of pelagic fish distribution and abundance in relation to a seismic shooting area off the Norwegian west coast. Fisheries Research, 67, 143-150.

Smith, M.E., Kane, A.S., Popper, A.N. (2004). Noise-induced stress response and hearing loss in goldfish (Carassius auratus). Journal of Experimental Biology, 207(3), 427-435.

Southall, B.L., Bowles, A.E., Ellison, W.T., Finneran, J.J., Gentry, R.L., Greene, C.R., Kastak, D., Ketten, D.R., Miller, J.H., Nachtigall, P.E., Richardson, W.J., Thomas, J.A., Tyack, P.L. (2007). Marine mammal noise exposure criteria: Initial scientific recommendations. Aquatic Mammals, 33, 411-521.

Spiga, I., Aldred, N., Caldwell, G.S. (2017). Anthropogenic noise compromises the anti-predator behaviour of the European seabass, Dicentrarchus labrax (L.). Marine pollution bulletin, 122(1-2), 297-305.

Szabo, T.M., Weiss, S.A., Faber, D.S., Preuss, T. (2006). Representation of auditory signals in the M-cell: role of electrical synapses. Journal of neurophysiology, 95(4), 2617-2629.

Tolimieri, N., Haine, O., Montgomery, J.C., Jeffs, A. (2002). Ambient sound as a navigational cue for larval reef fish. Bioacoustics, 12(2-3), 214-217.

Tyack, P.L. (2008). Implications for marine mammals of large-scale changes in the marine acoustic environment. Journal of Mammalian, 89(3), 549-558.

Vasconcelos, R.O., Amorim, M.C.P., Ladich, F. (2007). Effects of ship noise on the detectability of communication signals in the Lusitanian toadfish. The Journal of Experimental Biology, 210, 2104-2112.

Voellmy, I.K., Purser, J., Flynn, D., Kennedy, P., Simpson, S.D., Radford, A.N. (2014). Acoustic noise reduces foraging success in two sympatric fish species via different mechanisms. Animal Behaviour, 89, 191-198.
Wale, M.A., Simpson, S.D., Radford, A.N. (2013). Size-dependent physiological responses of shore crabs to single and repeated playback of ship noise. Biology Letters, 9, doi:10.1098/rsbl.2012.1194.

Wardle, C.S., T.J. Carter, G.G. Urquhart, A.D.F. Johnstone, A.M. Ziolkowski, G. Hampson, Mackie, D. (2001). Effects of seismic air guns on marine fish. Continental Shelf Research, 21, 1005-1027.

Wendelaar Bonga, S.E. (1997). The stress response in fish. Physiological reviews, 77(3), 591-625.

Wenz, G.M. (1962). Acoustic ambient noise in the ocean: spectra and sources. The Journal of the Acoustical Society of America, 34(12), 1936-1956.

Williams, R., Bain, D.E., Ford, J.K.B., Trites, A.W. (2002a). Behavioural responses of male killer whales to a 'leapfrogging' vessel. Journal of Cetacean Research and Management, 4, 305-310.

Williams, R., Trites, A.W., Bain, D.E., 2002b. Behavioural responses of killer whales (Orcinus orca) to whalewatching boats: opportunistic observations and experimental approaches. Journal of Zoology, 256, 255-270.

Williams, R., Erbe, C., Ashe, E., Beerman, A., Smith, J. (2014). Severity of killer whale behavioral responses to ship noise: a dose-response study. Marine Pollution Bulletin, 79, 254-260.

Wilson, M., Hanlon, R.T., Tyack, P.L., Madsen, P.T. (2007). Intense ultrasonic clicks from echolocating toothed whales do not elicit anti-predator responses or debilitate the squid Loligo pealeii. Biology Letters, 3, 225-227.

Wysocki, L.E., Dittami, J.P., Ladich, F. (2006). Ship noise and cortisol secretion in European freshwater fishes. Biological Conservation, 128(4), 501-508.

Wysocki, L.E., Davidson III, J.W., Smith, M.E., Frankel, A.S., Ellison, W.T., Mazik, P.M., Popper, A.N., Bebak, J. (2007). Effects of aquaculture production noise on hearing, growth, and disease resistance of rainbow trout Oncorhynchus mykiss. Aquaculture, 272(1-4), 687-697. 
Yılmaz, S., Ergün, S., Çelik, E.Ş. (2013). Effect of dietary herbal supplements on some physiological conditions of sea bass Dicentrarchus labrax. Journal of Aquatic Animal Health, 25(2), 98-103.

Yılmaz, S., Ergün, S., Çelik, E.Ş., Yigit, M. (2018a). Effects of dietary humic acid on growth performance, haemato-immunological and physiological responses and resistance of Rainbow trout, Oncorhynchus mykiss to Yersinia ruckeri. Aquaculture Research. 1-12, DOI: 10.1111/are. 13798

Y1lmaz, S., Ergün, S., Yigit, M. (2018b). Effects of dietary FARMARIN ${ }^{\circledR}$ XP supplement on immunological responses and disease resistance of rainbow trout ( $\mathrm{On}$ corhynchus mykiss). Aquaculture. 496, 211-220.
Yigit, M. (2007). The Triangle of Aquaculture Tourism and Open Sea (Akvakültür Turizm ve Açıkdeniz Üçgeni). Aquaculture \& Fisheries, 8, 26-30.

Yigit, M., Ergün, S., Bulut, M., Önal, U. (2006). Aquaculture and Tourism (Aquakültür ve Turizm), Aqualife of Turkey Suda Yasam Dergisi, 8, 60-63.

Yousefi, S., Hoseinifar, S.H., Paknejad, H., Hajimoradloo, A. (2018). The effects of dietary supplement of galactooligosaccharide on innate immunity, immune related genes expression and growth performance in zebrafish (Danio rerio). Fish and Shellfish Immunology, 73, 192196. 